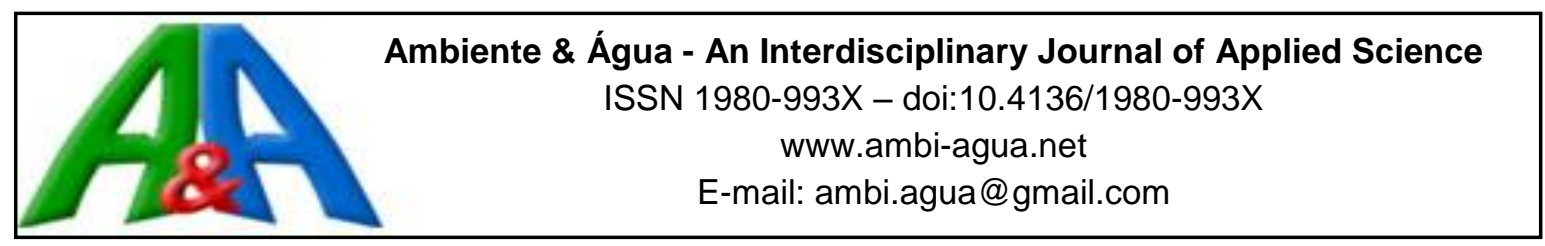

\title{
Evaluation of soil water storage in native forest and eucalyptus areas
}

\author{
doi:10.4136/ambi-agua.2195
}

Received: 04 Oct. 2017; Accepted: 22 Oct. 2017

\author{
Marcelo dos Santos Targa ${ }^{1 *}$; Getulio Teixeira Batista ${ }^{2}$; \\ Ana Aparecida da Silva Almeida1 ${ }^{1}$; Emilson Pohl' ${ }^{1}$; Geberson Ricardo de Paula ${ }^{3}$ \\ ${ }^{1}$ Universidade de Taubaté (UNITAU), Taubaté, SP, Brasil \\ Programa de Pós-graduação em Ciências Ambientais, Departamento de Ciências Agrárias \\ E-mail: targa.marcelo@gmail.com, anaparecida.almeida@gmail.com, emilsonpohl@gmail.com \\ ${ }^{2}$ Universidade de Taubaté (UNITAU), Taubaté, SP, Brasil \\ Instituto de Pesquisas Ambientais em Bacias Hidrográficas, Departamento de Ciências Agrárias \\ E-mail: gtbatista@gmail.com \\ ${ }^{3}$ Secretaria da Educação do Estado de São Paulo, Taubaté, SP, Brasil \\ Secretaria de Educação Estadual, Diretoria de Taubaté. E-mail: geberslp@ gmail.com \\ *Corresponding author
}

\begin{abstract}
In the region of the Paraíba do Sul river valley in the State of São Paulo, Brazil, pasture areas have been replaced by eucalyptus plantations, which can modify the dynamics of water in the soils of the region. The objective of this work was to evaluate the behavior of water in a Red-Yellow Latosol in two vegetative coverings, a six-year-old eucalyptus plantation, and a native forest, in the process of regeneration which began twenty years ago. The study was developed in the Una River basin from June 2009 to April 2011. The soil water potential was measured by 96 sensors (Watermark ${ }^{\mathrm{TM}}$ ) at the depths of 20,60 and $120 \mathrm{~cm}$. The Available Water Capacity (AWC) and weekly residual soil storage for each layer were calculated. It was observed that the three layers reacted to the processes of rainfall and evapotranspiration and that there was a difference between the storage of water in the soil in the eucalyptus and native forest areas. There was no water restriction in the studied period; however, the variations in native forest storage were smoother than the variations occurring for eucalyptus. In the mean of the whole period and for the three layers, the storage in the native forest and eucalyptus were $88 \%$ and $64 \%$ of Available Water Capacity ( $\mathrm{AWC}=183 \mathrm{~mm}$ ), respectively. These results show the native forest water conservation capacity in watersheds.
\end{abstract}

Keywords: watersheds, tensiometer, water use, forest.

\section{Avaliação do armazenamento de água no solo em áreas de floresta nativa e de eucalipto}

\section{RESUMO}

Na região do vale do rio Paraíba do Sul no Estado de São Paulo, Brasil, as áreas de pastagem vêm sendo substituídas por cultivos de eucalipto, o que pode modificar a dinâmica da água nos solos da região. Assim, o presente trabalho teve por objetivo avaliar o comportamento da água em Latossolo Vermelho-Amarelo em duas coberturas vegetais, uma plantação de eucalipto, de seis anos de idade, e uma floresta nativa, em processo de regeneração 
há vinte anos. $\mathrm{O}$ estudo foi desenvolvido na bacia hidrográfica do rio Una, no período de junho de 2009 a abril de 2011. Foram medidas semanalmente o potencial matricial de água no solo em 96 sensores (Watermark ${ }^{\mathrm{TM}}$ ), instados nas profundidades de 20, 60, e $120 \mathrm{~cm}$. Foram calculados a Capacidade de Água Disponível (CAD) e semanalmente o armazenamento residual do solo para cada camada. Foi observado que, as três camadas reagiram aos processos de precipitação pluvial e evapotranspiração e que houve diferença entre o armazenamento de água no solo nas áreas de eucalipto e de floresta nativa. Não houve restrição de água no período estudado, contudo, as variações no armazenamento em floresta nativa foi mais suave que as variações ocorridas para eucalipto. Na média de todo o período e para as três camadas o armazenamento na floresta nativa e eucalipto respectivamente foram de $88 \%$ e $64 \%$ da Capacidade de Água disponível $(\mathrm{CAD}=183 \mathrm{~mm})$ Esses resultados mostram a capacidade de conservação de água da floresta nativa em bacias hidrográficas.

Palavras-chave: bacias hidrográficas, tensiômetro, uso da água, floresta.

\section{INTRODUCTION}

The region of the Paraíba Valley, in the State of São Paulo, has potential for expanding eucalyptus cultivation due to its climate and the availability of large areas occupied by degraded pastures. This change in the vegetative cover of the pasture to eucalyptus may have an impact on the landscape, regional economy and water dynamics in the soil-plant-atmosphere system (Lima, 1996).

Water is extremely important to plant production, and its rational management, as a way to avoid its lack or excess, is decisive for the full development of plants and for the preservation of the environment. Because it is stored in the soil, a reservoir open to the atmosphere and to the horizons or deeper layers, it is important to quantify elements of the terrestrial phase of the hydrological cycle, such as storage capacity, flows occurring both on the surface and the infiltration and the evaporation, as well as in the deeper layers of the soil.

It is fundamental to analyze the behavior of water in the soil with eucalyptus cover and other vegetative cover, especially of native forest, since there is a great discussion in relation to water availability in watersheds with extensive areas planted with eucalyptus. Another important aspect to consider in the water consumption of a region is the modification of the use and occupation of the soil by extension of one economic activity to the detriment of others. In this sense, Arguello et al. (2010) estimated that there was an increase of $32.2 \%$ in the eucalyptus plantation area from 2001 to 2007 in the Paraíba Valley region and that this increase was mainly due to the substitution of pasture. According to Carriello and Vicens (2011) silviculture developed over pasture areas (55\%), secondary vegetation (15\%), gallery forest (9\%) and areas with exposed soil (7\%).

The reduction of soil water content and the lowering of the water table are problems attributed to eucalyptus monoculture. Lima and Zakia (2006) agree that cutting the eucalyptus causes problems of overuse of water at the beginning of the crop to return, because in the drier months natural forests draw water from the deeper layers of the soil, while the forest Eucalyptus plantation under development (regrowth or new planting) removes water from the soil surface, making it even drier.

The objective of this study was to evaluate soil water storage in the 0 to $20 \mathrm{~cm}, 20$ to 60 $\mathrm{cm}$ and 60 to $120 \mathrm{~cm}$ layers in a forest planted with eucalyptus (6 years) and in the native forest area in regeneration (20 years), through the monitoring of soil water potential and climatological water balance. 


\section{MATERIAL AND METHODS}

\subsection{Characterization of the study area}

The present study was carried out in eucalyptus forest and native forest, both located in the Una River basin (URB) affluent on the right bank of the Paraíba do Sul River, between the parallels $23^{\circ} 14^{\prime} 00^{\prime \prime} \mathrm{S}$ and $22^{\circ} 58^{\prime} 00^{\prime \prime} \mathrm{S}$ and and the meridians $45^{\circ} 37^{\prime} 00^{\prime \prime} \mathrm{W}$ and $45^{\circ} 17^{\prime} 00^{\prime \prime} \mathrm{W}$ (Figure 1). This basin is formed by the union of the Almas River with the Rocinha River and its tributaries, totaling an area of $476 \mathrm{~km}^{2}$, which corresponds to more than $80 \%$ of the area of the municipality of Taubaté (SP), which is $115 \mathrm{~km}$ from São Paulo-SP and $350 \mathrm{~km}$ from the city of Rio de Janeiro-RJ (Batista et al., 2005). The URB altitudes oscillate between 500 and 1,000 meters, with a boundary to the northeast by the Quebra Cangalha Mountain and to the southeast by the Jambeiro Mountain (CPTI, 2004).

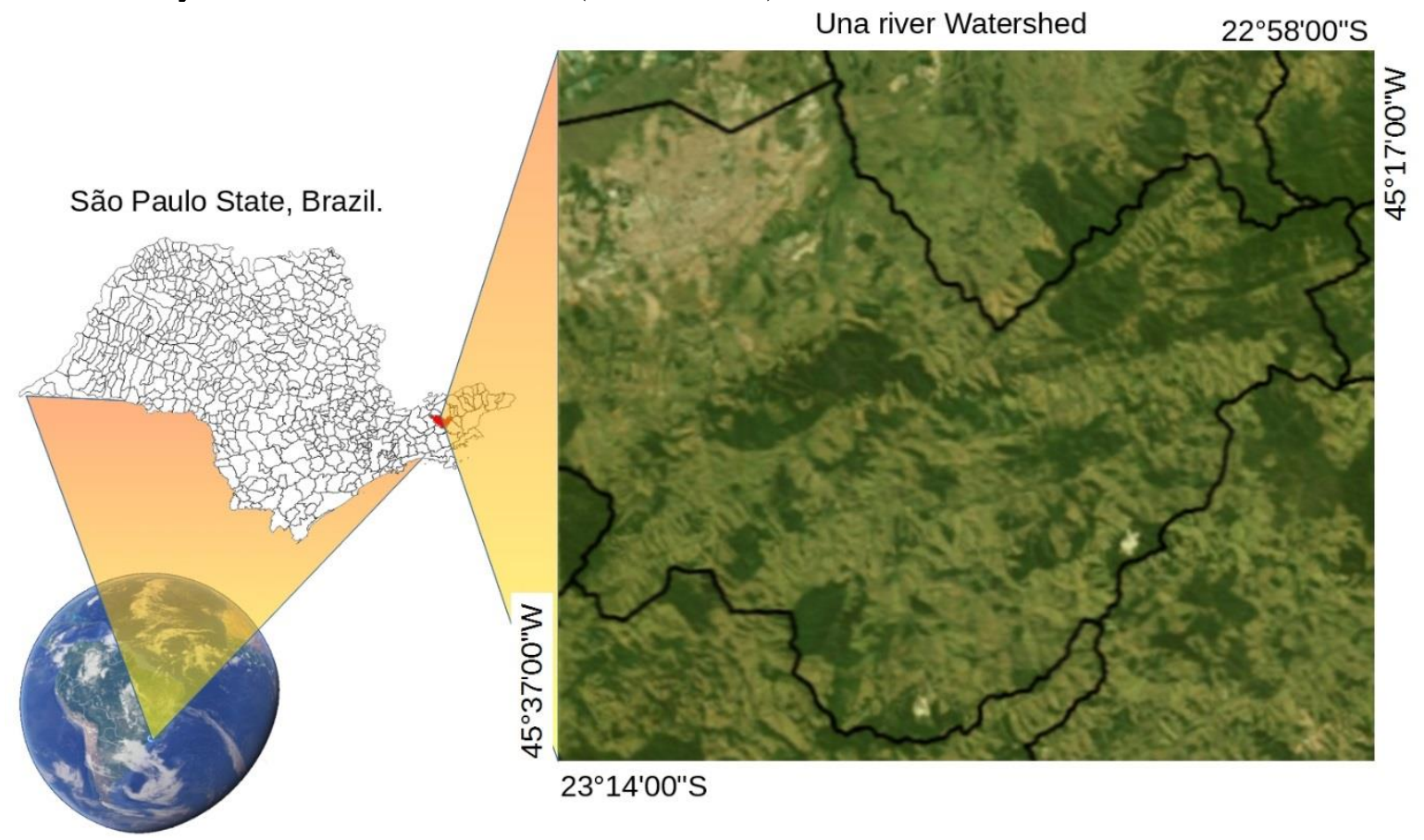

Figure 1. Location of the Una River Basin (URB).

Source: adapted from Batista et al. (2005).

The climate in the Taubate region is of the humid mesothermic type with drought in the months of June to August and precipitation from November to February (Fisch, 1999). Topographically, the region influences the variation of temperature and precipitation. In the mountains, winter temperatures are often below zero, while in the lower parts of the river basin average January temperatures of $32^{\circ} \mathrm{C}$ may occur.

According to Horikoshi and Fisch (2007) the soil water balance for Taubaté with data from 1992 to 2005 revealed a surplus of $263 \mathrm{~mm}$, since the total annual precipitation is $1336 \mathrm{~mm}$ and Evapotranspiration is $1073 \mathrm{~mm}$. They also observed a deficit of $34 \mathrm{~mm}$ in a 4-month period, but the surplus is 5 months, totaling $297 \mathrm{~mm}$.

The experimental area consisted of an area of vegetation of eucalyptus forest and native forest in Fazenda Una belonging to the Fibria SA company. This farm is located at URB, on the municipal road of Taboão, in the municipality of Taubaté, SP, at an average altitude of 728 and its geographic coordinates are as follows: $23^{\circ} 05^{\prime} 32^{\prime \prime} \mathrm{S}, 45^{\circ} 28^{\prime} 14^{\prime \prime} \mathrm{W}$. The variety of eucalyptus planted in the property is Eucalyptus urograndis spaced $3 \times 2 \mathrm{~m}$ and the native forest has been in the regeneration phase for more than 20 years and have the same soil conditions and slope. 
Soil analyzes were carried out at the Soil Laboratory of the Department of Agrarian Sciences of the University of Taubaté. In order to determine the specific mass of the soil and to survey its water retention curve, undisturbed soil samples were collected at depths of 20,60 and $120 \mathrm{~cm}$ by means of $50 \mathrm{~cm}^{3}$ volume metal rings.

The granulometric analysis was performed by the pipette method (Gee and Bauder, 1986; Kiehl, 1979), using sodium hydroxide $(\mathrm{NaOH} ; 1 \mathrm{~N})$ as the chemical dispersant. For the mechanical dispersion of the sample, a low-speed rotary agitator (35 RPM) was used, with stirring time of the soil samples of 16 hours.

The soil (ds) and particle (dp) densities were determined by the volumetric ring and anhydrous alcohol methods, respectively, according to the recommendations of Ferreira et al. (1990). The total soil porosity (p) was obtained from the specific masses of the soil and the particles, according to Reichardt and Timm (2004).

\subsection{Water tension in soil}

In the field, soil water content was determined indirectly using WatermarkTM sensors (Figure 2), which measure the soil water matrix potential in $\mathrm{kPa}$, which is converted to water content based on volume $\left(\mathrm{m}^{3} . \mathrm{m}^{-3}\right)$ by means of a soil water retention equation (Tracom, 2004).

The Watermark sensor (Figure 2a) consists of an electric resistance-type groundwater voltage measurement system composed of two concentric electrodes inserted in a granular matrix material. These electrodes connected to the external wiring are connected to a reader (Figure $2 b$ ) which, as a function of soil moisture, transforms this reading of electrical resistance into groundwater potential. The tensiometers were constructed in $3 / 4$ "PVC tubes in lengths of 30,70 and $130 \mathrm{~cm}$ with the voltage sensors positioned at the lower end. Wiring connects the sensors through the inside of the PVC pipes to the upper end, where they can be connected to the voltage meter.

Soil water retention curves relate the soil water potential $\left(\Psi_{\mathrm{m}}\right)$ and their volumetric water contents $(\theta)$ were determined in the Soil Physics Laboratory of the Agricultural Sciences Center of the Federal University of São Carlos, located in Araras, SP. In this determination the undisturbed soil samples were saturated with distilled water and placed in the Richards moisture extractors (Klute, 1986) at tensions of 10, 20, 30, 50, 100, 500, 1000 and $1500 \mathrm{kPa}$.

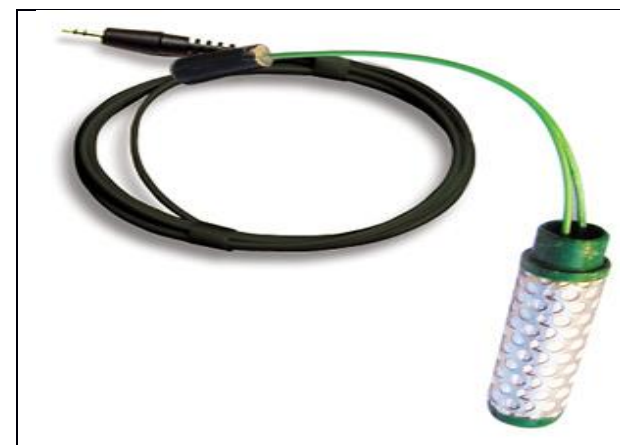

(a)

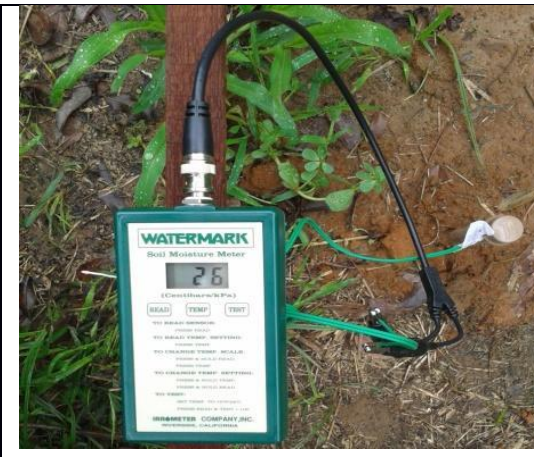

(b)

Figure 2. (a) WatermarkTM soil tension sensor and (b) WatermarkTM equipment for reading soil water potential $(\Psi \mathrm{m})$.

Tensiometers were installed in the soil in the layers of $0-20,20-60$ and $60-120 \mathrm{~cm}$ by means of soil drilling with a tread being equally distributed in 16 points, totaling 48 sensors in each of the areas according to Figure 3 . The measurements were made weekly in the period from July 2009 to February 2011. 


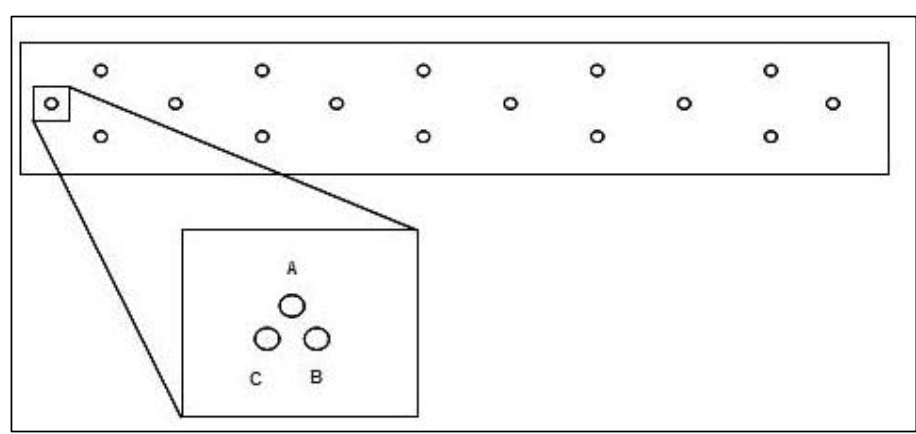

Figure 3. Distribution model of soil water tension sensors in the $0-20 \mathrm{~cm}(\mathrm{~A}), 20-60 \mathrm{~cm}(\mathrm{~B})$ and $60-120 \mathrm{~cm}(\mathrm{C})$ layers.

\subsection{Climatological water balance}

The Climatological Water Balance was performed according to the methodology of Thornthwaite and Mather (1955), from the electronic data sheet GD V.3.2-2002 (D'Angiolella and Vasconcellos, 2002), which uses information of average temperature, precipitation and available soil water that serves a wide variety of crops and diverse hydrological applications.

According to Thornthwaite and Mather (1955), the available water capacity (WC), regardless of the type of soil used for forest species, ranges from 150 to $300 \mathrm{~mm}$ (Pereira et al., 2002).

The meteorological data of precipitation $(\mathrm{mm})$ and air temperature $\left({ }^{\circ} \mathrm{C}\right)$ were collected at the Automatic Weather Station-A740, operated by the National Institute of Meteorology (INMET, 2009), located in the municipality of São Luiz do Paraitinga (SP), at $20 \mathrm{~km}$ of the experimental area, at an altitude of $870 \mathrm{~m}$ and coordinates $23^{\circ} 13^{\prime} 67^{\prime \prime} \mathrm{S}$ and $45^{\circ} 25^{\prime} 00^{\prime \prime} \mathrm{W}$.

The reference evapotranspiration data were calculated by the Penman-Monteith method, following the procedures proposed by Smith (1991) and Allen et al. (1998).

\section{RESULTS AND DISCUSSION}

\subsection{Soil characteristics of the experimental area}

The predominant soil in both the eucalyptus forest and the native forest is a Red-Yellow Latosol (EMBRAPA, 1999) with distribution of the granulometric fractions that allowed for it to classify as a clayey texture.

The values determined for soil density (ds), soil particle density (dp) and total porosity (p) in the native forest and eucalyptus areas for the different layers are presented in Table 1, where it is verified that both areas have similar characteristics in terms of these parameters. In general, the two areas are similar in terms of chemical characteristics, which can be explained by the accumulation of plant material on the surface and nutrient cycling (Paula et al., 2013).

Table 1. Soil and particle densities in $\mathrm{g} . \mathrm{cm}^{-3}$ and total soil porosity in $\%$ in native forest and eucalyptus areas.

\begin{tabular}{ccccccc}
\hline $\begin{array}{c}\text { layer } \\
(\mathrm{cm})\end{array}$ & $\mathrm{ds}$ & $\begin{array}{c}\text { native forest } \\
\mathrm{dp}\end{array}$ & $\mathrm{p}$ & $\mathrm{ds}$ & $\mathrm{dp}$ & $\mathrm{p}$ \\
\hline $0-20$ & 1.16 & 2.47 & 52.8 & 1.24 & 2.37 & 47.9 \\
$20-60$ & 1.27 & 2.42 & 47.7 & 1.29 & 2.48 & 47.9 \\
$60-120$ & 1.14 & 2.54 & 55.2 & 1.12 & 2.52 & 55.7 \\
Average & 1.19 & 2.48 & 51.9 & 1.22 & 2.46 & 50.5 \\
\hline
\end{tabular}

The water retention curves in the soil for native forest and eucalyptus areas for the $0-20$ $\mathrm{cm}$ layers; $20-60 \mathrm{~cm}$ and $60-120 \mathrm{~cm}$ are shown in Figure 4. The regression equations, of 
potential type, between volumetric water content $(\theta)$ in $\mathrm{m}^{3} \cdot \mathrm{m}^{-3}$ and the matric potential of soil water $\left(\Psi_{\mathrm{m}}\right)$ in $\mathrm{kPa}$ for the native forest area and eucalyptus, with their respective coefficients of $\left(\mathrm{R}^{2}\right)$ are given in Table 2 .

Table 2. Equations of matric potential $(\Psi \mathrm{m})$ and volumetric moisture $(\theta)$ for the $0-20 \mathrm{~cm}$ layers; $20-60 \mathrm{~cm}$ and $60-120 \mathrm{~cm}$ in the native forest and eucalyptus areas.

\begin{tabular}{ccccc}
\hline Layers $(\mathrm{cm})$ & native forest & $\mathrm{R}^{2}$ & eucalyptus & $\mathrm{R}^{2}$ \\
\hline $0-20$ & $\theta=0.3534 * \mathrm{~T}^{-0.08}$ & 0.99 & $\theta=0.4932 * \mathrm{~T}^{-0.095}$ & 0.99 \\
$20-60$ & $\theta=0.3821 * \mathrm{~T}^{-0.094}$ & 0.97 & $\theta=0.5637 * \mathrm{~T}^{-0.113}$ & 0.98 \\
$60-120$ & $\theta=0.3973 * \mathrm{~T}^{-0.107}$ & 0.94 & $\theta=0.6522 * \mathrm{~T}^{-0.145}$ & 0.99 \\
\hline
\end{tabular}

The available water capacity (CWA) in the soil for the layers (z) from 0 to $20 \mathrm{~cm} ; 20-60$ $\mathrm{cm}$ and $60-120 \mathrm{~cm}$ for the native forest and the eucalyptus areas were calculated by the difference between the water content of the soil based on volume in the field capacity and the permanent wilting point multiplied by the difference of the upper depth and of the layer by means of Equation 1. The residual water storage in the soil was also calculated by Equation 2.

$C W A=\left(\theta_{F C}-\theta_{P W P}\right) * Z_{u}-Z_{l}$

$R W S=\left(\theta_{a}-\theta_{P W P}\right) * Z_{u}-Z_{l}$

Where:

CWA is the available soil water capacity in mm, considered as the maximum soil water storage capacity;

RWS is the residual water storage in mm, considered as the maximum soil water storage capacity;

$\theta_{F C}$ is the Volumetric water content at the field capacity in $\mathrm{cm}^{3} . \mathrm{cm}^{-3}$;

$\theta_{P W P}$ is the Volumetric water content at the wilting point permanent in $\mathrm{cm}^{3} . \mathrm{cm}^{-3}$;

$\theta_{a}$ is the Current or residual volumetric water content in $\mathrm{cm}^{3} . \mathrm{cm}^{-3}$;

$\mathrm{Z}_{\mathrm{u}}$ e $\mathrm{Z}_{\mathrm{l}}$ are the Upper (u) and lower depths (l) of the layer considered.

The values of the volumetric water content $\left(\mathrm{cm}^{3} \cdot \mathrm{cm}^{-3}\right)$ in the Field Capacity $\left(\theta_{F C}\right)$ and the Permanent Wilt Point $\left(\theta_{P W P}\right)$, for the layers $0-20 \mathrm{~cm} ; 20-60 \mathrm{~cm}$ and $60-120 \mathrm{~cm}$ for the two vegetation cover areas (Table 3) were obtained from the soil water characteristic curve equations described in Table 2. With these values it was possible to apply Equation 1 to calculate the Capacity (CWA) in mm for each layer and also for the entire profile studied. The results show that with the exception of the $60-120 \mathrm{~cm}$ layer, in the others the soil water storage of the native forest area is slightly higher than that of the soil in the eucalyptus forest. The CWA in the whole profile is of the order of $183 \mathrm{~mm}$ for the native forest and $175 \mathrm{~mm}$ for eucalyptus. These results may be related to the total porosity being slightly larger in the native forest area. 


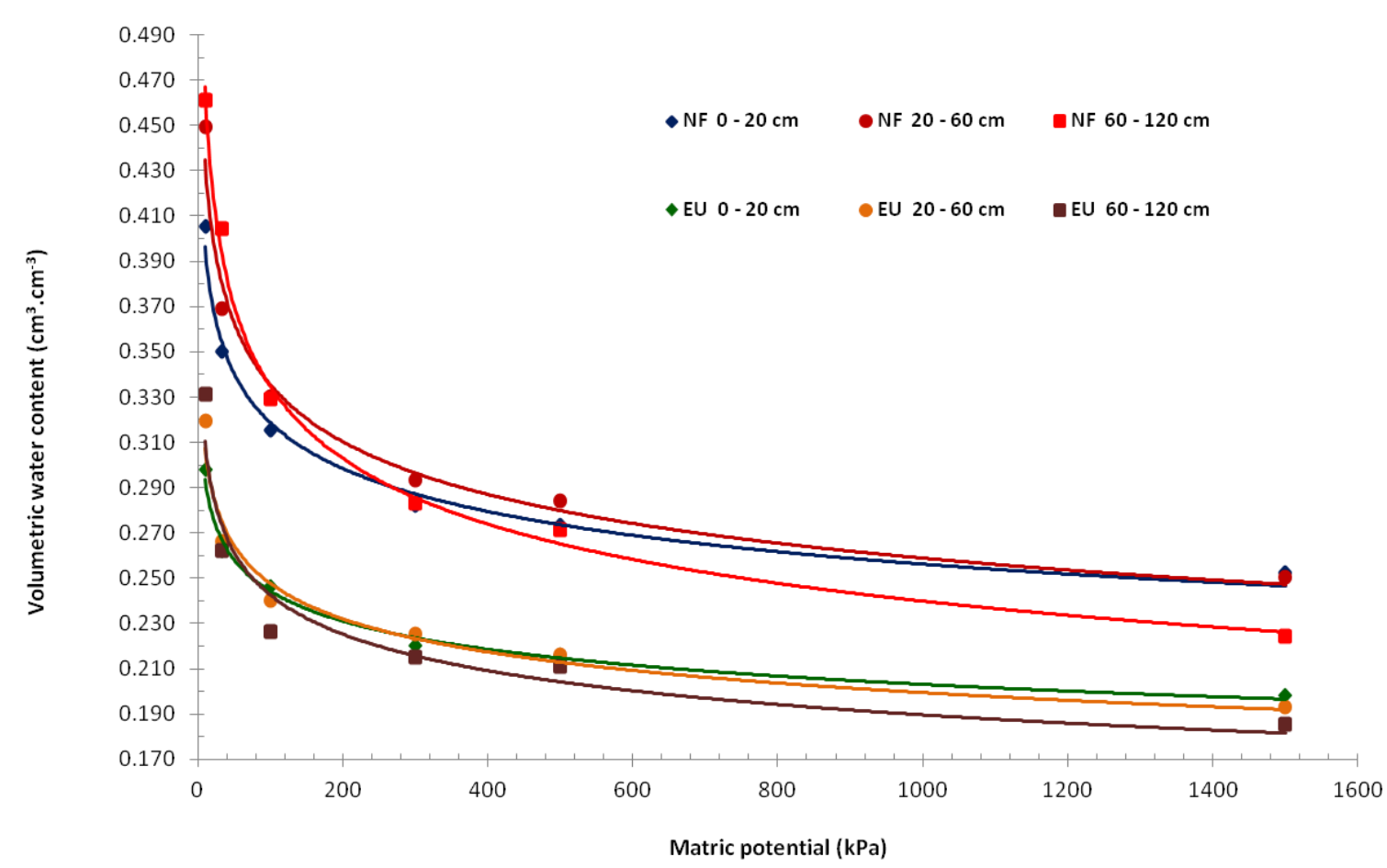

Figure 4. Characteristic soil water curves for the $0-20 \mathrm{~cm}$ layers; $20-60 \mathrm{~cm}$ and $60-120 \mathrm{~cm}$ in the native forest (NF) and eucalyptus areas (EU).

Table 3. Volumetric water content in $\mathrm{cm}^{3} . \mathrm{cm}^{-3}$ in the field capacity and Permanent wilting point for the layers of $0-20 \mathrm{~cm} ; 20-60 \mathrm{~cm} ; 60-120 \mathrm{~cm}$ and $0-120 \mathrm{~cm}$ in the areas of native forest and eucalyptus.

\begin{tabular}{ccccccc}
\hline Áreas & \multicolumn{3}{c}{ native forest } & \multicolumn{3}{c}{ eucalyptus } \\
\hline $\begin{array}{c}\text { Layers } \\
(\mathrm{cm})\end{array}$ & $\left(\theta_{\mathrm{FC}}\right)$ & $\left(\theta_{\mathrm{PWP}}\right)$ & $\begin{array}{c}\text { CWA } \\
(\mathrm{mm})\end{array}$ & $\left(\theta_{\mathrm{FC}}\right)$ & $\left(\theta_{\mathrm{PWP}}\right)$ & $\begin{array}{c}\text { CWA } \\
(\mathrm{mm})\end{array}$ \\
\hline $0-20$ & 0.267 & 0.136 & 26.14 & 0.354 & 0.247 & 21.56 \\
$20-60$ & 0.275 & 0.125 & 60.21 & 0.381 & 0.247 & 53.37 \\
$60-120$ & 0.274 & 0.111 & 97.50 & 0.393 & 0.226 & 100.25 \\
$0-120$ & 0.272 & 0.124 & 183.85 & 0.376 & 0.240 & 175.25 \\
\hline
\end{tabular}

\subsection{Hydric balance}

Figure 5 shows the climatological water balance in the soil for the period from May 2009 to February 2011. In this balance, the CWAvalue of $183.85 \mathrm{~mm}$ was adopted, corresponding to the maximum storage value determined for the $0-120 \mathrm{~cm}$ layer in the native forest area.

Figure 5a shows the climatological water balance for the period from May 2009 to April 2010, where it can be observed that in the months of May to September 2009, characterized as dry period, the water balance in the region was deficit; however, $284 \mathrm{~mm}$ of precipitation occurred in that period, which constituted a replacement of water in the soil as of June 2009.

The climatic water balance in the whole period indicated an accumulation of $258.7 \mathrm{~mm}$, evidencing water excess in the period from November 2009 to the second half of March 2010. Figure $5 \mathrm{~b}$ shows the climatological water balance for the following period of May 2010 to April 2011, which shows that although there was $180 \mathrm{~mm}$ precipitation in the dry period, the climatic water balance was negative from the second fortnight of April 2010 until November 2010, owing to a replacement and water surplus from November to March 2011. 
(a)

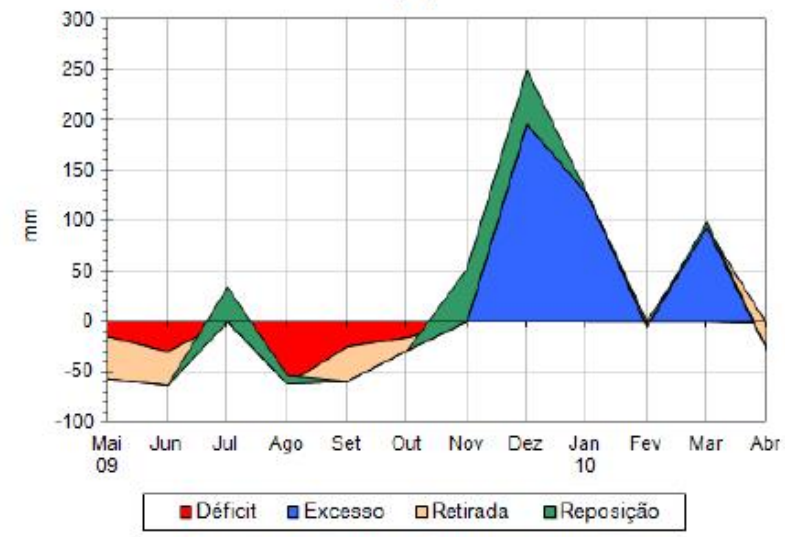

(b)

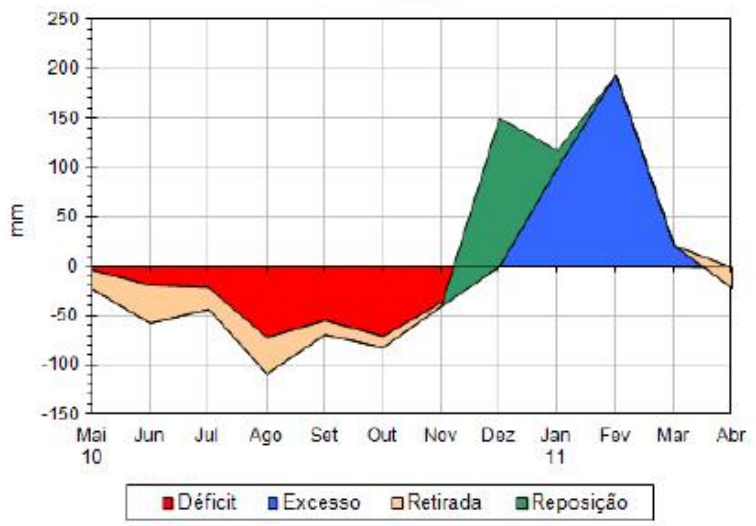

Figure 5. Climatological water balance 2009 to 2010 (a) and 2010 to 2011 (b).

\subsection{Variation of soil water storage}

Figure 6a shows the positive balance during the study period between precipitation and monthly evapotranspiration. The data collected indicate that there was a surplus of $516 \mathrm{~mm}$ of water in the soil during the study period. The total precipitation in the period was $3194.5 \mathrm{~mm}$, and it should be noted that in the two periods from November to February it rained about 65\% of the total in the period studied. The accumulated evapotranspiration in the period was $2677.8 \mathrm{~mm},(83.82 \%)$ of the total precipitation.

Figures $6 \mathrm{~b}$ and $6 \mathrm{c}$ show soil storage values in the $0-20 \mathrm{~cm}$ layers; $20-60 \mathrm{~cm}$ and $60-120$ $\mathrm{cm}$ in the native forest and eucalyptus areas, respectively. It can be observed that there was a difference in soil water storage for the two vegetable groups during the studied period. In general, storage variations accompanied the precipitation regime, indicating that water penetrated and was stored in the soil, but also accompanied the evapotranspiration regime, demonstrating that the greater loss of water occurred at times of low occurrence of precipitation.

Figure $6 \mathrm{~b}$ and $6 \mathrm{c}$ also show the maximum storage capacities in each layer, respectively, established by the Available Water Capacity (CWA) values of each layer. Throughout the profile, the CWA calculated by Equation 1 of the native forest area $(183 \mathrm{~mm})$ was slightly higher than the eucalyptus area.

Figure $6 \mathrm{~b}$ shows that the variations in the residual water storage in the soil of the native forest area were smoother and remained in most of the study period at values below the maximum storage in the three layers, but on average the values were very close to the maximum of each layer. In the $60-120 \mathrm{~cm}$ layer, the mean residual storage of the entire study period was of the order of $23 \mathrm{~mm}$ against $26 \mathrm{~mm}$ of the maximum. The storage exceeded the maximum at three times, mainly due to the occurrence of high rains that added more than $600 \mathrm{~mm}$ in November and December of 2009, and in December of 2010, when the rain reached $300 \mathrm{~mm}$.

On the other hand, the residual storage in the layers of $0-20 \mathrm{~cm}$ and $20-60 \mathrm{~cm}$ reached the maximum on 9 occasions. In the $20-60 \mathrm{~cm}$ layer, the average residual storage during the whole period was of the order of $55 \mathrm{~mm}$ against $60 \mathrm{~mm}$ of the maximum in this layer and at 6 times exceeded the maximum. The mean residual storage $(25 \mathrm{~mm})$ was more uniform and close to the maximum $(26 \mathrm{~mm})$ in the $0-20 \mathrm{~cm}$ layer and at 10 times reached the maximum.

This greater homogeneity in the native forest area, where the average residual storage in the 3 layers remained around $89 \%$ of the maximum storage, can be a result of the heterogeneity of the forest species that present differences in the water absorption of the soil and, according to Lima et al. (2012), demonstrate their ability to conserve water in the soil. 


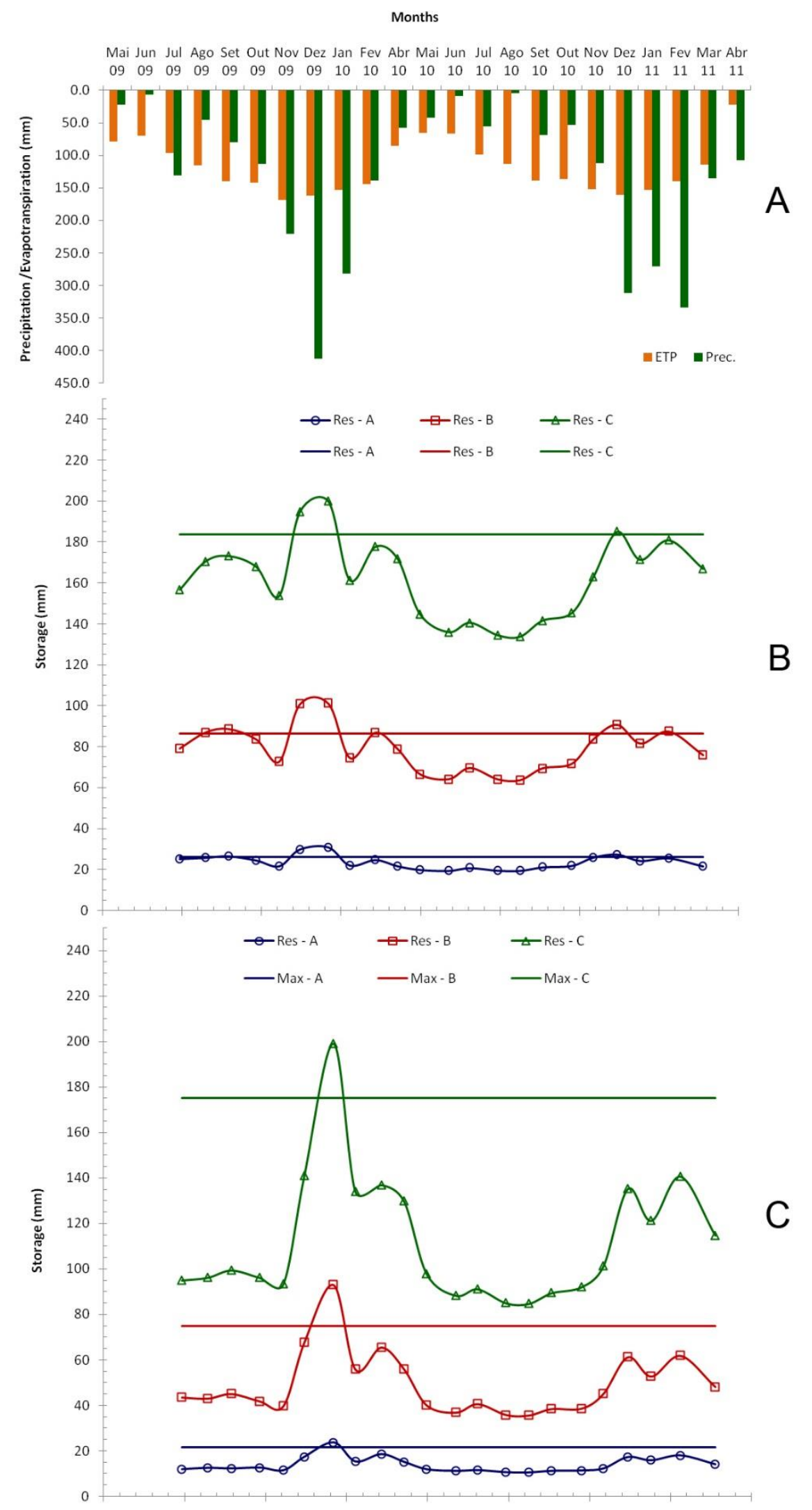

Figure 6. (a) Precipitation and Evapotranspiration in native forest and eucalyptus area. (b) Average monthly water storage for the 0-20, 20-60 and 60-120 cm layers in the soil under native forest. (c) Average monthly water storage for the 0-20, 20-60 and $60-120 \mathrm{~cm}$ layers in the soil under eucalyptus forest. 
Figure $6 \mathrm{c}$ shows that the variations in the residual water storage in the soil of the eucalyptus area over time were more pronounced, averaging for the whole period only $64 \%$ of the maximum storage for the three layers studied. However, only once, in December 2009, in the three layers, the residual storage exceeded the maximum, which coincided with an excessive precipitation of more than $400 \mathrm{~mm}$ and in most was always below. The storage of the $60-120$ $\mathrm{cm}$ layer effectively declined so much that during a period of 2 months it was close to $53 \mathrm{~mm}$; maximum storage of the layer of $20-60 \mathrm{~cm}$ was below that limit for 7 months. In the $20-60 \mathrm{~cm}$ layer, the mean residual storage value was $35 \mathrm{~mm}$ versus $53 \mathrm{~mm}$ of the maximum for this layer. In the 0-20 layer, the mean residual storage was $14 \mathrm{~mm}$ versus $21 \mathrm{~mm}$ (maximum storage value in that layer).

In forest systems, whether planted forest, such as eucalyptus, or native forest, the root system can supply water at greater depths. The mean residual storage of the native forest area in relation to the eucalypt forest was $51 \mathrm{~mm}$ higher. The variations in the storage of the layer up to $20 \mathrm{~cm}$ and from 20 to $60 \mathrm{~cm}$ in the eucalyptus crop may be due to the fact that the root system, composed of fine roots $(<2 \mathrm{~mm})$, is concentrated up to $50 \mathrm{~cm}$ deep, with a predominance of almost 58 (Witschoreck et al., 2003) and, also, due to the 0 to $20 \mathrm{~cm}$ layer, the soil-air interface is formed (Paula et al., 2013).

Another important aspect, as already observed (Paula, et al., 2013), conditions of higher temperature at the soil surface and lower temperature in the crown of eucalyptus trees may result in greater water loss due to transpiration in the eucalyptus area compared to native forest area in the same soil condition.

The results of this study demonstrated the conservation capacity of native forest water to the detriment of eucalyptus. However, the average residual storage of $64 \%$ of the maximum storage for eucalyptus cultivation is normal, since in irrigated systems it is common to irrigate when the water reserve in the soil reaches values of 50 to $70 \%$ of the maximum storage.

\section{CONCLUSION}

The use of water content sensors proved to be efficient for the measurement in different layers in a practical and fast way, reflecting the entry and exit of soil water in times of precipitation and drought.

The native forest area had a greater storage capacity ( $88 \%$ of maximum) of water in the soil than the eucalyptus area (64\% of the maximum) at the three depths during the studied period. These differences demonstrate the importance of native forest in the conservation of water in watersheds.

\section{ACKNOWLEDGMENTS}

To the CNPq for the support to the Behavior of Water in Soil under Eucalyptus Vegetable Cover and Native Forest Essences, Process No. 480990 / 2007-7. To the company Fibria S.A. for the access to the study area, Fazenda Una.

\section{REFERENCES}

ARGUELLO, F. V. P. et al. Distribuição espacial de plantios de eucalipto no trecho paulista da bacia hidrográfica Rio Paraíba do Sul, SP, Brasil. Revista Ambi-Água, v. 5, n. 3, p. 133 146, 2010. http://dx.doi.org/10.4136/ambi-agua.158

ALLEN, R. G.; PEREIRA, L. S.; RAES, D.; SMITH, M. Crop evapotranspiration. Guidelines for predicting crop water requirements. Rome: FAO, 1998. 300p. (FAO: Irrigation and Drainage Paper, 56). 
BATISTA, G. T.; TARGA, M. S.; DIAS, N. W.; CATELANI, C. S. Modelo de banco de dados ambientais georreferenciados voltado à recuperação e preservação de recursos hídricos de uma bacia de médio porte, o modelo da bacia do rio Una, Paraíba do Sul, SP. In: SIMPÓSIO BRASILEIRO DE RECURSOS HÍDRICOS, 16., 2005, João Pessoa. Anais.... Rio de Janeiro: ABRH, 2005. v. 1. p. 1-16.

CARRIELLO, F.; VICENS, R. S. Silvicultura de eucalipto no vale do Paraíba do Sul/SP no período entre 1986 e 2010. In: SIMPÓSIO BRASILEIRO DE SENSORIAMENTO REMOTO - SBSR, 15., 2011, Curitiba. Anais... São José dos Campos: INPE, 2011. p. 6403.

COOPERATIVA DE SERVIÇOS, PESQUISAS TECNOLÓGICAS E INDUSTRIAIS - CPTI. Plano das Bacias hidrográficas do rio Paraíba do Sul. Osasco, 2004.

D’ANGiOlella, G. L. B.; VASCONCELlOS, V. L. D. Cálculo do balanço hídrico climatológico com diferentes métodos para estimativa da evapotranspiração potencial, em planilhas Excel ${ }^{\mathrm{TM}}$. In: CONGRESSO BRASILEIRO DE METEOROLOGIA, 12, 2002. Anais... Foz do Iguaçu: SBMET, 2002. 1 CD-Rom.

EMBRAPA. Centro Nacional de Pesquisa de Solo. Sistema Brasileiro de Classificação de Solos. Rio de Janeiro, 1999. 412 p.

FERREIRA, M. E.; CRUZ, M. C. P.; FERREIRA Jr., M. E. Avaliação da Fertilidade empregando o sistema IAC de análise de Solo. Jaboticabal: UNESP, FCAV, 1990.

FISCH, G. F. Distribuição da precipitação em Taubaté, Vale do Paraíba (SP). Revista Biociências, v. 5, n. 2, p. 7- 11, 1999.

GEE, G. W.; BAUDER, J. W. Particle-size analysis. In: KLUTE, A. (Ed.). Methods of soil analysis. Part 1. Physical and mineralogical methods. Madison: American Society of Agronomy, 1986. p. 383-411.

HORIKOSHI, A. S.; FISCH, G. Balanço hídrico atual e simulações para cenários climáticos futuros no município de Taubaté, SP. Brasil. Revista Ambi-Água, v. 2, n. 2, p. 33-46. 2007. http://dx.doi.org/10.4136/ambi-agua. 25

INSTITUTO NACIONAL DE METEOROLOGIA - INMET. Dados meteorológicos. Plataforma de Coleta de Dados A740. 2009. Available in http: www.inmet.gov.br. Access: mar. 2011.

KIEHL, E. J. Manual de edafologia: relações solo-planta. São Paulo: Ceres, 1979. 264p.

KLUTE, A. (Ed). Methods of soil analysis. Part 1. Physical and mineralogical methods. Madison: American Society of Agronomy, 1986. p. 1188.

LIMA, W. P. Impacto ambiental do eucalipto. 2. ed. São Paulo: EdUSP, 1996. 301 p.

LIMA, W. P.; ZAKIA, M. J. B. As florestas plantadas e a água. São Carlos: Rima, 2006. $226 \mathrm{p}$.

LIMA, W. de P. et al. Forest plantations and water consumption: a strategy for hydrosolidarity. International Journal of Forestry Research, 2012. Available in: http://dx.doi.org/10.1155/2012/908465. Access: 15 jul. 2017.

PAULA, G. R. et al. Avaliação do comportamento da umidade do solo em áreas de eucalipto e de floresta nativa. Revista Ambi-Água, v. 8, supl., p. 237-252, 2013. http://dx.doi.org/10.4136/ambi-agua.1419 
PEREIRA, A. R. ANGELOCCI, L. R.; SENTELHAS, P. C. Agrometeorologia: fundamentos e aplicações práticas. Guaíba: Agropecuária, 2002.

REICHARDT, K.; TIMM, L. C. Solo, planta e atmosfera: conceitos, processos e aplicações. 2. ed. Barueri: Manole, 2004. 478 p.

SMITH, M. Report on the expert consultation on procedures for revision of FAO guidelines for predictions of crop water requirements. Rome: FAO, 1991. 45p.

THORNTHWAITE, C. W.; MATHER, J. R. The water balance: publications in climatology. New Jersey: Drexel. Institute of Technology, 1955. 104 p.

TRACOM IMP. EXP. E COM LTDA. Watermark sensores para monitoramento da umidade do solo. Available in: http://www.tracom.com.br/Irrometer/pdf/watermark.pdf. 2004. Access in: 21 maio 2009.

WITSCHORECK, R.; SCHUMACHER, M. V.; CALDEIRA, M. V. W. Estimativa da biomassa e do comprimento de raízes finas em Eucalyptus urophylla S.T. Blake no município de Santa Maria-RS. Revista Árvore, v. 27, n. 2, p. 177-183, 2003. http://dx.doi.org/10.1590/S0100-67622003000200008 